\title{
Pathogens Removal in a Sustainable and Economic High-Rate Algal Pond Wastewater Treatment System
}

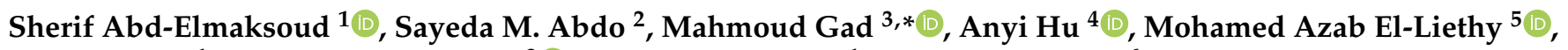 \\ Neveen Rizk ${ }^{1}$, Mohamed A. Marouf ${ }^{3}{ }^{1}$, Ibrahim A. Hamza ${ }^{1}$ and Hala S. Doma ${ }^{6}$ \\ 1 Environmental Virology Laboratory, Water Pollution Research Department, National Research Centre, \\ Giza 12622, Egypt; sherifnrc@yahoo.com (S.A.-E.); neveenmagdynrc@gmail.com (N.R.); \\ ibrahimnrc@gmail.com (I.A.H.) \\ 2 Hydrobiology Laboratory, Water Pollution Research Department, National Research Centre, \\ Giza 12622, Egypt; sayedamohammed2015@gmail.com \\ 3 Environmental Parasitology Laboratory, Water Pollution Research Department, National Research Centre, \\ Giza 12622, Egypt; mohamednrc80@gmail.com \\ 4 CAS Key Laboratory of Urban Pollutant Conversion, Institute of Urban Environment, \\ Chinese Academy of Sciences, Xiamen 361021, China; ayhu@iue.ac.cn \\ 5 Environmental Microbiology Laboratory, Water Pollution Research Department, National Research Centre, \\ Giza 12622, Egypt; mohamedazabr@yahoo.com \\ 6 Industrial and Municipal Wastewater Treatment Technology Laboratory, Water Pollution \\ Research Department, National Research Centre, Giza 12622, Egypt; Sahadoma15@gmail.com \\ * Correspondence: mi.saleh@nrc.sci.eg or mahmoudafw@yahoo.com; Tel.: +20-1061132911
}

Citation: Abd-Elmaksoud, S.; Abdo, S.M.; Gad, M.; Hu, A.; El-Liethy, M.A.; Rizk, N.; Marouf, M.A.; Hamza, I.A.; Doma, H.S. Pathogens Removal in a Sustainable and Economic High-Rate Algal Pond Wastewater Treatment System. Sustainability 2021, 13, 13232. https://doi.org/10.3390/ su132313232

Academic Editors: Muftah H. El-Naas and Keng Yuen Foo

Received: 11 November 2021 Accepted: 25 November 2021 Published: 29 November 2021

Publisher's Note: MDPI stays neutral with regard to jurisdictional claims in published maps and institutional affiliations.

Copyright: (c) 2021 by the authors. Licensee MDPI, Basel, Switzerland. This article is an open access article distributed under the terms and conditions of the Creative Commons Attribution (CC BY) license (https:/ / creativecommons.org/licenses/by/ $4.0 /)$.

\begin{abstract}
This study evaluates the efficiency of a sustainable technology represented in an integrated pilot-scale system, which includes a facultative pond (FP), a high-rate algal pond (HRAP), and a rock filter (RF) for wastewater treatment to produce water that complies with the Egyptian standards for treated wastewater reuse. Still, limited data are available on pathogen removal through HRAP systems. Thus, in this study, the performance of the integrated system was investigated for the removal of Escherichia coli (E. coli), coliform bacteria, eukaryotic pathogens (Cryptosporidium spp., Giardia intestinalis, and helminth ova), somatic coliphages (SOMCPH), and human adenovirus (HAdV). Furthermore, physicochemical parameters were determined in order to evaluate the performance of the integrated system. The principal component analysis and non-metric multidimensional scaling analysis showed a strong significant effect of the integrated system on changing the physicochemical and microbial parameters from inlet to outlet. The mean $\log _{10}$ removal values for total coliform, fecal coliform, and E. coli were 5.67, 5.62, and 5.69, respectively, while $0.88 \log _{10}$ and $1.65 \log _{10}$ reductions were observed for HAdV and SOMCPH, respectively. The mean removal of Cryptosporidium spp. and Giardia intestinalis was 0.52 and $2.42 \log _{10}$, respectively. The integrated system achieved $100 \%$ removal of helminth ova. The results demonstrated that the system was able to improve the chemical and microbial characteristics of the outlet to acceptable levels for non-food crops irrigation. Such findings together with low operation and construction costs of HRAPs should facilitate wider implementation of these nature-based systems in remote and rural communities. Overall, this study provides a novel insight into the performance of such systems to eliminate multiple microbial pathogens from wastewater.
\end{abstract}

Keywords: HRAP technology; pilot-scale system; wastewater treatment; pathogens removal

\section{Introduction}

Sanitation, global food security, and renewable energy are among the most imperative sustainable development goals of the century adopted by the united nations $[1,2]$. There are over 2.4 billion people worldwide who do not have access to adequate sanitation [2], and more than 400,000 people die as a result of diarrhea caused by poor sanitation [3]. In addition, more than 800,000 people die each year because of no access to safe drinking water 
and basic sanitation [3]. Approximately 1.5 billion people in the world discharge sewage into the environment without treatment [4]. The main source of pathogen contamination in surface waters is the discharge of wastewater effluents to surface water [5]. Since the removal of pathogens and the safe reuse of treated sewage primarily depend on the treatment technology used, an integrated system including FP, HRAP, and RF was proposed to overcome these challenges.

In most countries, traditional centralized sewage treatment systems have successfully controlled water contamination [6]. However, treatment technologies such as the activated sludge process are rather expensive and not entirely feasible for widespread application in rural areas [7]. Furthermore, they are limited and insufficient when facing wastewater treatment regulations [8]. Therefore, selecting cost-effective and efficient alternative wastewater treatment methods is crucial, particularly in low-income countries. In terms of the total number of facilities, algal-based wastewater treatment systems (e.g., high-rate algal ponds and waste stabilization ponds) are among the most commonly used treatment technologies worldwide [9-12]. HRAPs have recently been regarded as an appropriate option for wastewater treatment due to their significant advantages over traditional pond systems, including simplicity, lower construction and operation costs, low energy consumption, robustness, and sustainability, as well as the ability to reduce nutrients, micropollutants, and pathogenic microbes [13-16]. HRAPs were designed to improve the efficiency of stabilization ponds by being shallower to allow for light penetration, producing more oxygen at a faster pace, and having a shorter retention time. In addition, the amount of space required was lowered. HRAPs, unlike traditional WWTPs, do not require external aeration or chemical inputs throughout the treatment process due to microalgae photosynthesis [17,18].

HRAPs are designed to stimulate algal growth in order to facilitate the symbiotic breakdown of organic waste by algae and bacteria [19]. Because of the mixing and shallow ponding, the pond is more exposed to sun radiation [20]. Compared to deeper traditional WSPs (Waste Stabilization Ponds), this increased sun exposure promotes higher algae photosynthesis and more organic waste decomposition [19]. Solar radiation, specifically ultraviolet B (UVB), is the primary factor involved in the inactivation of pathogens $[21,22]$. HRAPs can produce equal- or better-quality effluents with a considerably shorter theoretical hydraulic retention time (THRT) compared to WSPs $[23,24]$. The shorter retention period reduces the needed reactor capacity and, as a result, the surface area of the HRAP. This decrease in THRT and surface area reduces evaporation and improves the volume of effluents available for reuse purposes [13,24]. Several studies have investigated the removal of bacterial and viral indicators in HRAPs $[13,16,25,26]$. Most of these studies were conducted on a pilot-scale and/or lacked sufficient data for deep analysis. Future studies to understand the mechanisms underlying the removal of pathogens and indicators in HRAP systems are required [27]. Additionally, large-scale studies to evaluate the removal of a wide range of pathogens via HRAPs are also needed.

The World Health Organization (WHO) highlighted 16 distinct bacterial pathogens, 11 helminth groups, 9 pathogenic viruses groups, and 4 groups of protozoa that are significant to sanitation [3]. Helminth ova is one of the main targeted pathogens according to the WHO guidelines for aquaculture and agriculture wastewater reuse [28]. Total coliforms (TC), E. coli, and fecal coliform (FC) are often used as indicators for evaluating the quality of treated wastewater and have been proposed to indicate the existence of pathogenic microorganisms $[29,30]$. Their presence can be a good indication of fecal contamination. However, the limitations associated with the use of traditional fecal indicator organisms have been recognized in the literature, particularly as they can sometimes be limited in their ability to represent overall pathogen levels [31]. Bacteriophage and HAdV have been recommended as more credible indicators of wastewater microbiological quality than bacterial indicators, owing to their stability and tolerance to wastewater treatment processes. Indeed, the indicators cannot predict the presence of a wide range of pathogens [32]. In addition, the efficiency of pathogen removal (i.e., viruses, protozoa, and parasitic helminths) in 
HRAPs is not well studied yet [27]. Therefore, this study aims to fill the gap of knowledge about the efficiency of the integrated system with HRAP as the core stage for the removal of pathogens and microbiological indicators in wastewater. Evaluating the removal of pathogens from the system has significant indications for understanding not only the performance of treatment methods, but also the potential risks connected with the reuse of the treated wastewater.

\section{Materials and Methods}

\subsection{The Design of HRAP System and Samples Collection}

The integrated biological treatment system applied in this study consisted of FP followed by HRAP, and an RF was installed and fed with the HRAP effluent to remove algal biomass from the final treated effluent as shown in Figure 1. The system was installed at the Zenin wastewater treatment plant, Giza, Egypt. The Primary FP consisted of a polyvinyl tank with a $1.5 \mathrm{~m}$ depth and a $1 \mathrm{~m}^{3}$ volume, with continuous fed and screened raw municipal wastewater with a 5-day hydraulic retention time (HRT). The HRAP has a $20.95 \mathrm{~m}^{2}$ surface area, a $0.2 \mathrm{~m}$ effective wastewater depth, and a $4.3 \mathrm{~m}^{3}$ volume. The pond was fed continuously with the FP effluent at HRT for 5 days. The wastewater moves in the HRAP via an electric fan (paddlewheel) attached to the pond, which was set to a rotational speed generating a linear flow rate of $0.2 \mathrm{~m} \mathrm{~s}^{-1}$.

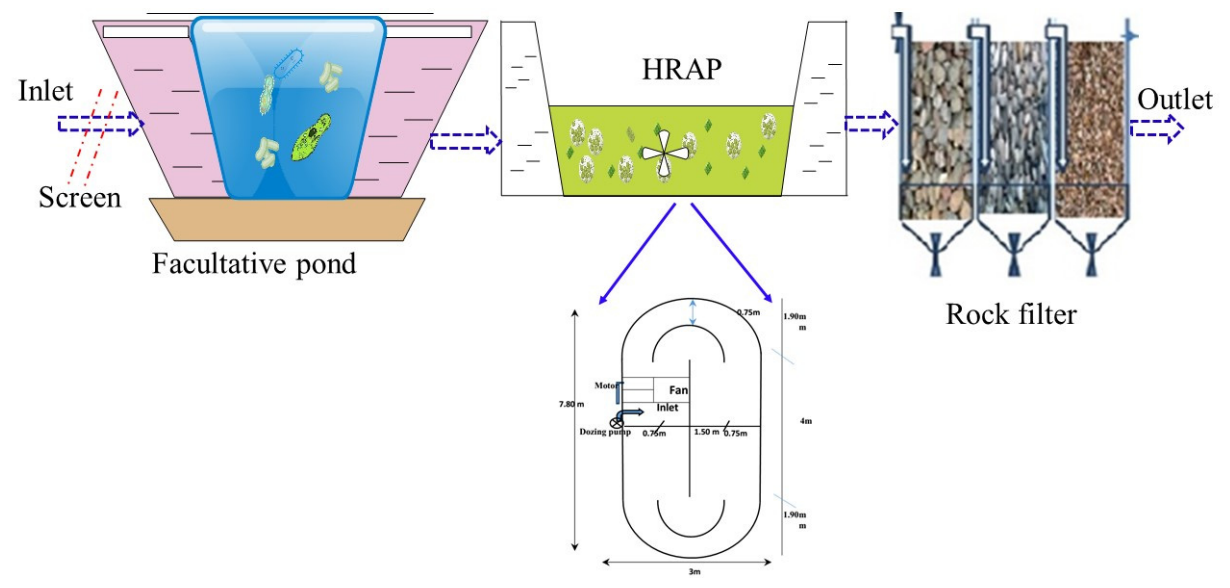

Figure 1. Flow diagram of the treatment steps.

To separate or harvest the algal biomass that remained in the HRAP effluent, the RF system was introduced. It consisted of three identical units with a $0.6 \mathrm{~m}$ depth and a $0.4 \mathrm{~m}$ width and length with an effective volume of $34 \mathrm{~L} /$ unit. It was provided by a sedimentation cone at the lower point to collect algae and solids (Figure 1). The system was constructed from polyvinyl chloride (PVC) sheets. The units were filled with different sizes of rocks that ranged $8-12 \mathrm{~cm}$ in the first unit, $4-8 \mathrm{~cm}$ in the second unit, and $2-4 \mathrm{~cm}$ in the third unit, with a $10 \mathrm{~h}$ detention time. The HRAP effluent overflowed continuously from the top to the bottom of the RF unit, thus 1part of the algal biomass settled in the bottom of the RF, and the other part stuck to the surface of the rocks. Samples were taken from the inlet (raw wastewater) and each treatment stage (Figure 1). Twenty-one batches were collected in sterile containers from May to November 2020 and analyzed in the National Research Centre laboratories within $3 \mathrm{~h}$ of the collection. The sample volume for parasitic helminths and protozoa analysis was 5 L [33]. For viral analysis, 5 L of each sample was collected [34]. For bacterial indicator examination, each sample was collected in a one L sterile bottle [35]. The sample volume for physicochemical parameters and algal analysis was $3 \mathrm{~L}$. 


\subsection{Physicochemical, Bacteriological, and Algal Community Analysis}

The physicochemical parameters including $\mathrm{pH}$, ammonia nitrogen $\left(\mathrm{NH}_{4}-\mathrm{N}\right)$, nitritenitrogen $\left(\mathrm{NO}_{2}-\mathrm{N}\right)$, total Kjeldahl nitrogen $(\mathrm{TKN})$, nitrate-nitrogen $\left(\mathrm{NO}_{3}-\mathrm{N}\right)$, total phosphorus (TP), total chemical oxygen demand (CODtot), soluble chemical oxygen demand (CODsol), biological oxygen demand (BODtot), soluble biological oxygen demand (BODsol), and total suspended solids were carried out according to international standard methods [36]. TC, FC, and E. coli were determined using the most probable number (MPN) method [36]. The algal analysis was carried out by collecting different sub-samples from inside the HRAP at different depths, and these sub-samples were mixed to form one sample, then concentrated by centrifugation at $2000 \mathrm{RPM}$ for $15 \mathrm{~min}$, and examined using Sedgewick Rafter cells. The identification of the algal community to the species level was performed microscopically (Olympus X3 microscope, Olympus Corporation, Tokyo, Japan) according to the key of freshwater algae [36,37]. The growth rate of algal biomass was assessed by determining the chlorophyll a (CHLA) content [36].

\subsection{Virological and Parasitological Analyses}

SOMCPH was propagated in tryptone broth inoculated on an exponentially growing bacteria host strain (E. coli) to prepare a stock suspension [38]. In order to concentrate adenoviruses from wastewater samples, the VIRADEL protocol was followed as described previously [39]. Nucleic acids were extracted using the QIAamp DNA Blood Mini Kit (Qiagen, Hilden, Germany) according to the manufacturer's instructions. Helminths were detected microscopically after floatation using zinc sulphate $[33,40]$.

The pathogens investigated in this study were adenovirus [41], Cryptosporidium spp., [42], and Giardia intestinalis [43]. To quantify the target pathogens in the samples, a qPCR reaction was performed in a $20 \mu \mathrm{L}$ reaction volume using a Maxima SYBR Green qPCR master mix kit (Thermo Scientific, Waltham, MA, USA). The reaction mixture was composed of $5 \mu \mathrm{L}$ of the DNA template, $10 \mu \mathrm{L}$ of the master mix, $0.5 \mu \mathrm{L}$ from each primer (forward and reverse) (Table 1), and $4 \mu \mathrm{L}$ of Nuclease-free water. The PCR temperature conditions were $95^{\circ} \mathrm{C}$ for $10 \mathrm{~min}$ and 45 cycles of $15 \mathrm{~s}$ at $95^{\circ} \mathrm{C}$ and $1 \mathrm{~min}$ at $60^{\circ} \mathrm{C}$. Nucleasefree water was also included in each run as a negative control [34]. Absolute quantification of genome equivalents (gen. eq.) was performed by comparing cycle threshold $(\mathrm{Ct})$ values to the DNA standard, which were included in every qPCR run. DNA standards were prepared as previously described by Rizk and Hamza (2021). The limits of detection for the assay were determined as $\leq 10$ gen. eq. per reaction.

Table 1. Nucleotide sequences of qPCR primers.

\begin{tabular}{|c|c|c|c|}
\hline & Primer & Sequence $\left(5^{\prime}-3^{\prime}\right)$ & Reference \\
\hline \multirow{2}{*}{ Cryptosporidium spp. } & COWP-F & CAAATTGATACCGTTTGTCCTTCTG & \multirow{2}{*}{ [42] } \\
\hline & COWP-R & TGGTGCCATACATTGTTGTCCT & \\
\hline \multirow{2}{*}{ Adenovirus } & Q1 & GCCACGGTGGGGTTTCTAAACTT & \multirow{2}{*}{ [41] } \\
\hline & Q2 & GCCCCAGTGGTCTTACATGCACATC & \\
\hline \multirow{2}{*}{ Giardia duodenalis } & $\beta$-Giardin P241-F & CATCCGCGAGGAGGTCAA & \multirow{2}{*}{ [43] } \\
\hline & $\beta$-Giardin P241-R & GCAGCCATGGTGTCGATCT & \\
\hline
\end{tabular}

\subsection{Statistical Analysis}

The principal component analysis (PCA) based on the Euclidean distance matrix was employed to characterize the patterns of physicochemical parameters in inlet and outlet samples. Non-metric multidimensional scaling (NMDS) analysis based on the BrayCurtis distance index was used to map pathogens, bacterial, and viral indicators in inlet and outlet samples. The permutational multivariate analysis of variance (PERMANOVA) and the analysis of similarity (ANOSIM) were used to test the significance of differences 
for physicochemical parameters or microbiological parameters between inlet and outlet samples [44]. The Wilcoxon statistical test was used to investigate the significance of the wastewater treatment technology for improving the physicochemical and biological parameters. Statistical analyses and visualization were performed using Origin (Pro) (OriginLab Corporation, Northampton, MA, USA) and PRIMER v.7.0.17 (Quest Research Limited, Auckland, New Zealand).

\section{Results and Discussion}

\subsection{The Performance of the HRAP System}

In this study, the microalgal community structure constituted three major algal strains, namely pediastrum gracillimum, Dictyospharium sp., and Scenedesmus sp. (Table S1 and Figure S1). A mixed species assemblage exhibited improved algal biomass and culture stability and good biomass production (Table S1). The results indicated that the maximum CHLA content was detected when the pond was dominant with Pediastrum gracilimum where the maximum CHLA concentration was $9.16 \mathrm{mg} / \mathrm{L}$ in the HRAP. The abundant species in the algal community was affiliated to the group Chlorophyta (e.g., genera; Scenedimus, Micractinium, Microcystis, Mucidosphaerium, and Pediastrum), and Bacillariophyta and Cyanophyta were also represented in the HRAP. All genera recorded in HRAP over the course of this study were known to be prominent constituents of microalgal communities in shallow and highly enriched systems $[45,46]$.

The PCA ordination showed a clear separation of the physicochemical parameters between the samples from the inlet and outlet, indicating a strong significant influence of the treatment (Figure 2). These results were confirmed by PERMANOVA $(p<0.001)$ and ANOSIM ( $p<0.001)$. The PCA vectors for nutrients (e.g., $\left.\mathrm{NH}_{4}-\mathrm{N}\right)$ and organic pollution parameters (e.g., BOD and COD) revealed an association with inlet samples, indicating an efficient system's operation (Figure 2). The physicochemical characteristics of the inlet and outlet are presented in Figure 3 and Table S2. The results showed that the COD in the inlet and outlet ranged between 229.00 to $404.00 \mathrm{mg} / \mathrm{L}$ and 38.00 to $100.00 \mathrm{mg} / \mathrm{L}$ with mean values of 315.40 and $56.00 \mathrm{mg} / \mathrm{L}$, respectively (Figure 3a). The BOD ranged between $118.00-187.00 \mathrm{mg} / \mathrm{L}$ and $10.00-27.00 \mathrm{mg} / \mathrm{L}$ in the inlet and outlet, respectively (Figure 3a). The overall removal rates of COD and BOD were $82.24 \%$ and $89.26 \%$, respectively (Figure $3 b$ ). The Wilcoxon statistical test revealed a strong significant removal of COD $(p<0.001)$ and BOD $(p<0.001)$ (Figure 3a). The removal of BOD via HRAP system ranged between 22 and 93.4\% was reported elsewhere [16,47-49]. A strong significant removal (Wilcoxon test: $p<0.001)$ of TSS $(92.09 \%), \mathrm{NH}_{4}-\mathrm{N}(89.39 \%)$, and TKN $(59.51 \%)$ was observed as well (Figure 3). The reported removal of ammonium ranged between 21.89 and $94 \%$ with a median of 77\% [47-52]. Algal photosynthesis generates the oxygen necessary for heterotrophic bacteria to degrade organic materials. Then, algae assimilate nutrients and $\mathrm{CO}_{2}$ released during the oxidation process [53]. In HRAPs, photosynthesis and nutrient assimilation are enhanced by continuous passing of the algae between the clear surface and dark bottom in vertical circulation cycles using paddlewheels [46]. The removal of TP via the integrated system was 38.43\% (Figure 3b). The reported TP removal ranged between 10.48 and $97.2 \%$ with a median of $42.73 \%$ [48,52,54,55]. pH-dependent precipitation and algal biomass incorporation were assumed to be the main mechanisms responsible for TP removal [56]. Additionally, the efficiency of nutrient removal in HRAP is influenced by the parameters that affect the growth and activity of algae, such as the detention time, temperature, and sun radiation [56].

As an extra benefit, HRAP systems can recover resources from the wastewater through the utilization of algal biomass that can be used as fertilizers, feed, and feedstock for biofuel production [57]. Microalgae have a number of advantages over plants, including the ability to thrive all year and low reliance on water requirements [58]. Moreover, the concentration of other elements (e.g., $\mathrm{NH}_{4}-\mathrm{N}$ and TKN) showed a significant decrease in the outlet (Figure 3) due to their consumption by algae (Table S2 and Figure 3). In 
particular, the structure of the microalgal community in HRAP can significantly improve nutrient removal [56].

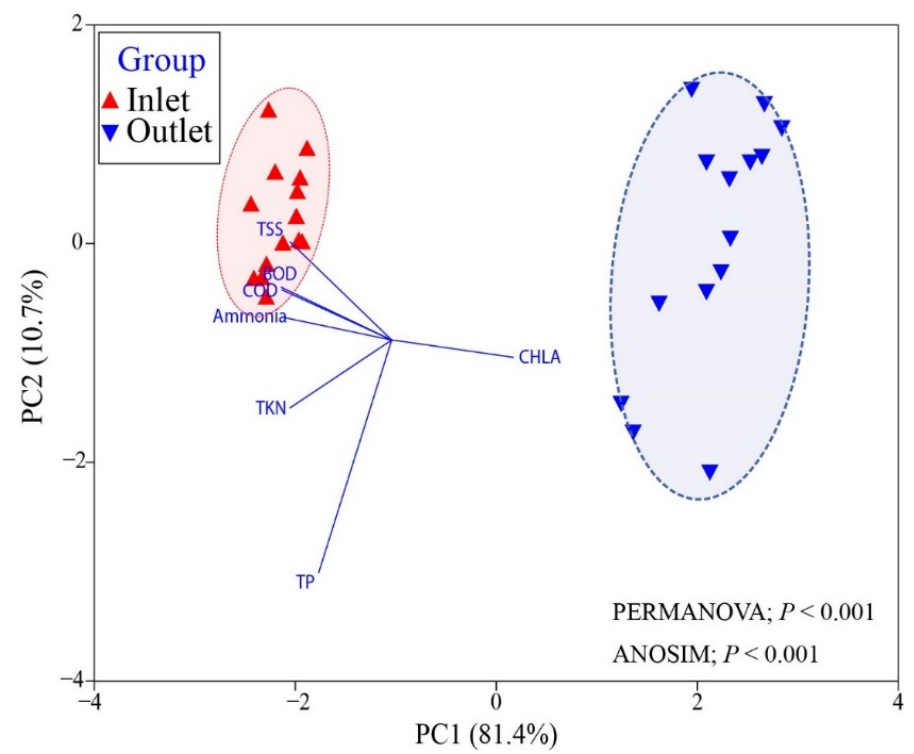

Figure 2. PCA for environmental parameters in the inlet and outlet of the integrated system.

(a)

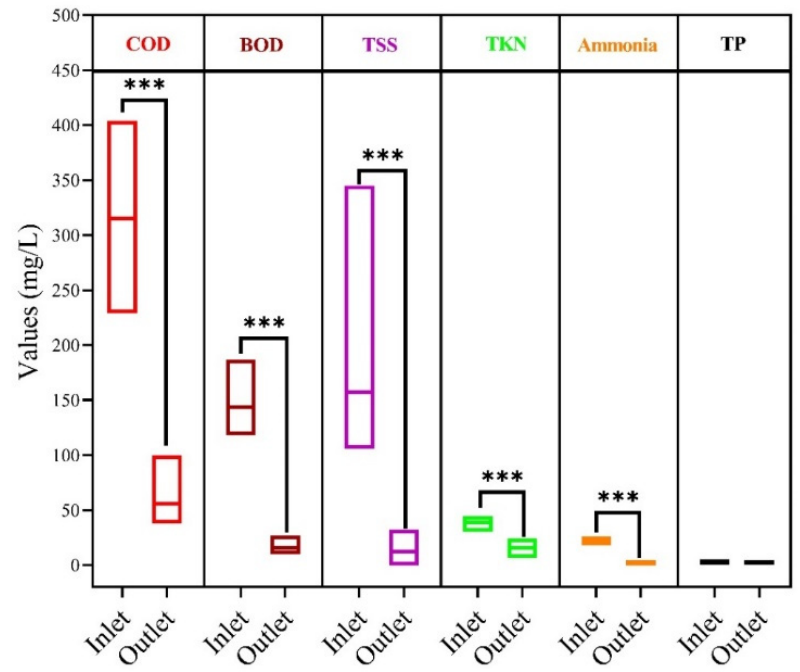

(b)

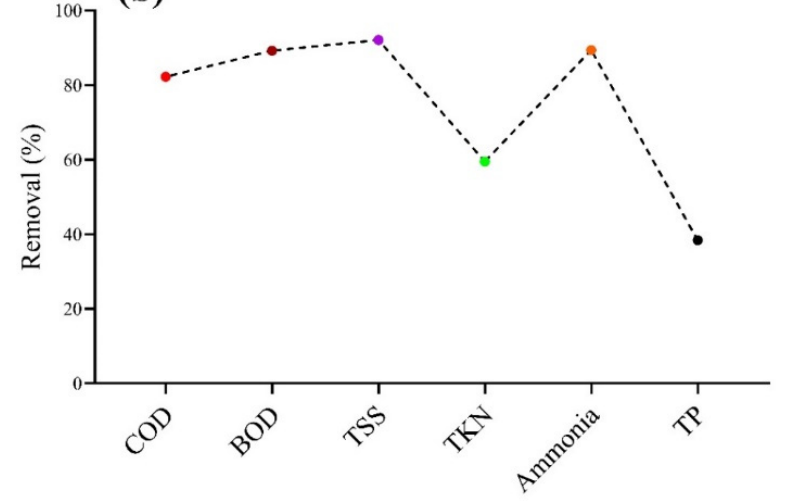

Figure 3. (a) Box and Whiskers showing the measurements of environmental parameters for the inlet and outlet of the integrated system, (b) their overall removal rates. ${ }^{* * *} p \leq 0.001$. 


\subsection{Pathogens Removal}

The NMDS ordination provides a good representation (stress: 0.08) for mapping the pathogens and indicators in inlet and outlet samples. The results of NMDS showed a clear dissimilarity between the inlet and outlet samples in terms of microbial pathogens and indicators (Figure 4$)$. The results of PERMANOVA $(p<0.001)$ and ANOSIM $(p<0.001)$ confirmed the NMDS findings (Figure 4). The concentration of bacterial and viral indicators in inlet and outlet wastewater samples was summarized in Figure 5. The concentration of TC ranged from 7.04 to $9.81 \log _{10}$ in inlet samples and in outlet samples was 2.30 to $4.04 \log _{10}$ (Figure 5). The concentration of FC ranged from 6.66 to $9.59 \log _{10}$ and 2.04 to $3.88 \log _{10}$ in inlet and outlet samples, respectively, whereas E. coli concentrations ranged from 6.32 to $9.46 \log _{10}$ and between 1.84 and $3.81 \log _{10}$ in inlet and outlet samples, respectively (Figure 5). Furthermore, the average removal of TC, FC, and E. coli was 5.66, 5.63 , and $5.70 \log _{10}$, respectively. Buchanan and colleagues found a lower removal value (mean $\log _{10}=2.75$ ) of E. coli in treated effluent obtained from HRAP when fed from FP effluent [13], and this could be due to the pilot-scale system presented here including three treatment stages (i.e., FP, HRAP, and RF). In other words, the RF stage in this system could play a significant role in pathogen removal. Additionally, the viral indicator, $\mathrm{SOMCPH}$, showed a higher mean concentration of $6.67 \log _{10} \mathrm{PFU} / \mathrm{L}$ in the inlets than in outlet samples $\left(5.02 \log _{10} \mathrm{PFU} / \mathrm{L}\right)$, with average removal of $1.65 \log _{10}$. The present results were consistent with Espinosa et al. (2021), who reported 5.16 and $1.54 \log _{10}$ removal of E.coli and SOMCPH, respectively, using an upflow anaerobic sludge blanket (UASB) reactor followed by HRAP [25]. Meanwhile, Verbyla et al. (2015) reported lower removal for bacteria ranging from 1.2 to $1.6 \log _{10}$ in HRAPs. Furthermore, the data for the removal of bacterial indicators were higher than those in other studies, which ranged from 1.76 to $2.19 \log _{10}[13,14,59]$. The integrated system removed bacterial (i.e., TC, FC, and E. coli) and viral (i.e., SOMCPH) indicators significantly (Wilcoxon test: $p<0.01$ ). Fecal indicator bacteria (FIB), such as FC and E. coli, are widely utilized to as an alert to the potential fecal contamination of a water source [60]. However, FIB (e.g., E. coli) are more susceptible to elimination in wastewater treatment than many viruses [32].

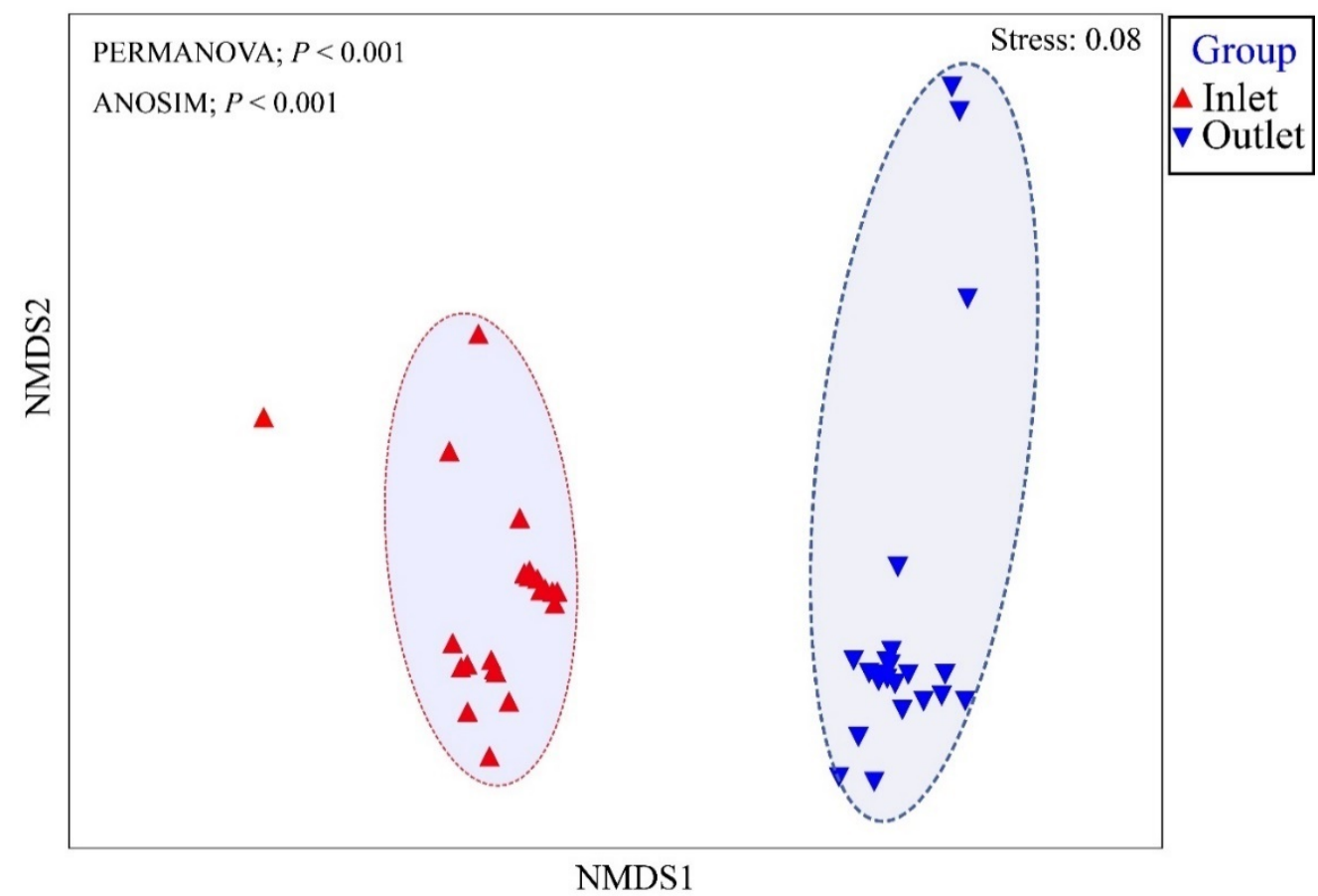

Figure 4. NMDS plot of pathogens and indicators based on dissimilarities calculated using the Bray-Curtis distance. 


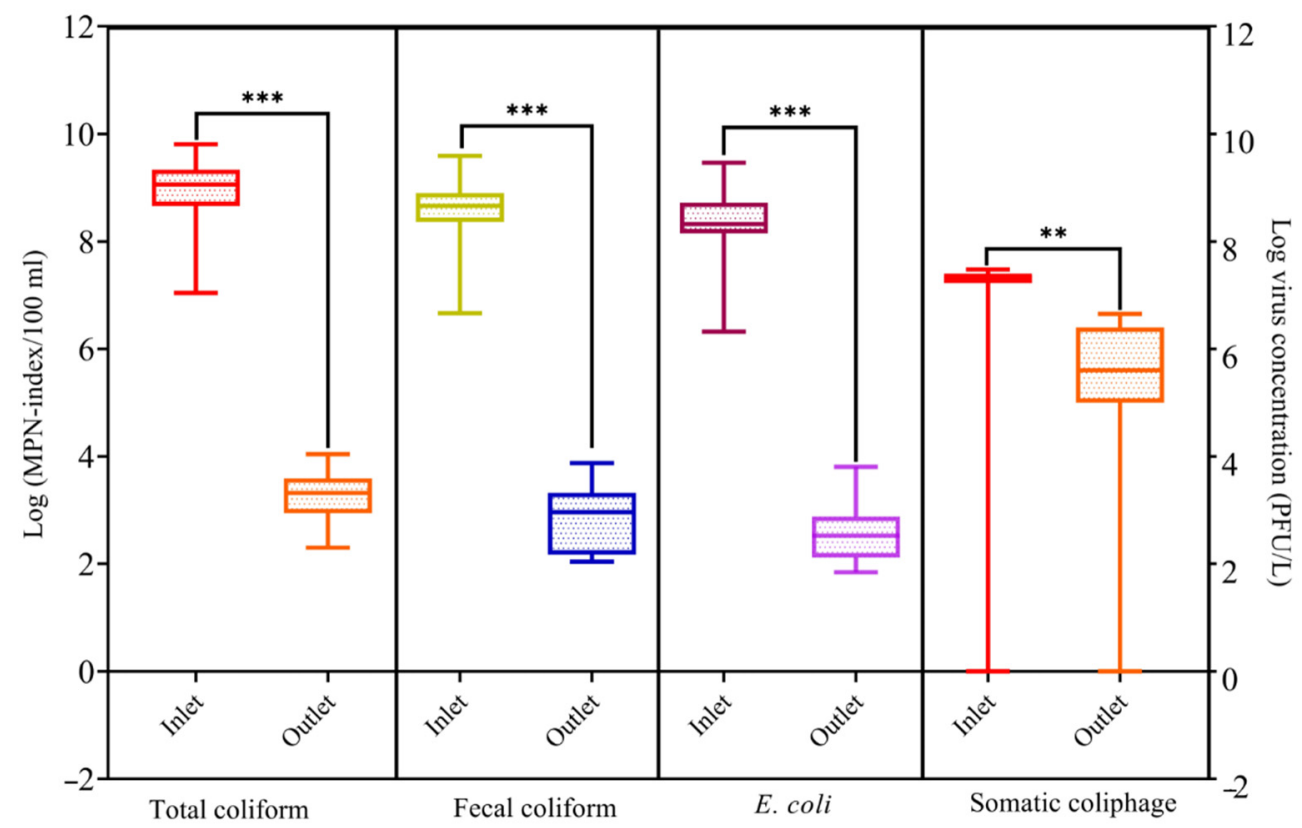

Figure 5. Box and whiskers plot showing the concentrations of bacterial and viral indicators in inlet and outlet samples. ${ }^{* *} p \leq 0.01,{ }^{* *} p \leq 0.001$.

A higher removal ability of the E. coli through the treatment system may provide a misleading impression to some practitioners that other pathogens are likewise removed or reduced to the same extent, which might not be the case. If the removal of E. coli is high, the treated effluent may not be suitable for reuse based on WHO (2006) guidelines, which suggest that 3 to $6 \log _{10}$ reduction of the pathogen at wastewater treatment plants can properly protect public health [61]. To maximize the benefits of wastewater reuse, it is important to control the pathogens to protect public health [56]. Since the bacterial and viral indicators revealed no correlation with the pathogens in the current research (Figure 6) and in previous studies [62,63], it is imperative to investigate the ability of an integrated system for removing the pathogens. The present study targets the most common waterborne pathogens (i.e., adenovirus, Cryptosporidium, and Giardia intestinalis) in Egypt (Figure 7) and parasitic nematodes (Figure S2) according to the Egyptian standard for treated wastewater reuse. Indeed, no truly universal indicators can represent pathogens [27]. Thus, a decrease in the number of indicators is not necessarily associated with the removal of different pathogens (e.g., viruses or protozoa) $[27,64]$.

The Wilcoxon test showed that the integrated treatment system could remove the pathogens (i.e., Giardia intestinalis and adenovirus) significantly $(p<0.05)$ (Figure 7). The mean $\log _{10}$ removal of protozoan Giardia intestinalis was $2.42 \log _{10}$ GC/L and the maximum removal reached was $4.68 \log _{10} \mathrm{GC} / \mathrm{L}$. The mean $\log _{10}$ removal of Cryptosporidium was $0.52 \log _{10} \mathrm{GC} / \mathrm{L}$, with maximum removal of $1.90 \log _{10} \mathrm{GC} / \mathrm{L}$, while the mean removal of adenovirus was $0.88 \log _{10} \mathrm{GC} / \mathrm{L}$ (Figure 7). Consistent removal of Cryptosporidium parvum (1.54-1.70 $\log _{10}$ ) was recorded elsewhere [21]. The integrated system showed $100 \%$ removal of parasitic helminth ova (Figure S2). The viability of helminth ova was reduced by 60 and $90 \%$ in the two experimental pilot-scale HRAPs working parallel at 4 and 10 days HRT, respectively [65]. Pathogen removal in HRAPs relies on environmental factors, such as sunlight, $\mathrm{pH}$, dissolved oxygen (DO), temperature, as well as predation $[10,66]$. Pathogens could also be removed from the liquid fraction via sedimentation after adsorption to solid particles [67]. Settling is generally accepted to be the main removal mechanism for protozoa and helminths [68,69]. Other factors, such as predation, sunlight, $\mathrm{pH}$, and $\mathrm{NH}_{4}-\mathrm{N}$ toxicity act as the main contributors to FIB and parasites removal [27]. One mechanism that has been established for the removal of viruses from wastewater is the adsorption to solids and their subsequent removal via sedimentation or filtration $[70,71]$. 
Removing different pathogens by the same mechanism does not necessarily occur at the same rate for all pathogens. For instance, UV light in HRAPs can damage viruses and bacteria; however, viruses are more tolerant than bacteria [72,73]. Moreover, HRAPs reduced viruses, protozoa, and bacteria at varying rates because of their structural and genetic compositions $[27,74,75]$.

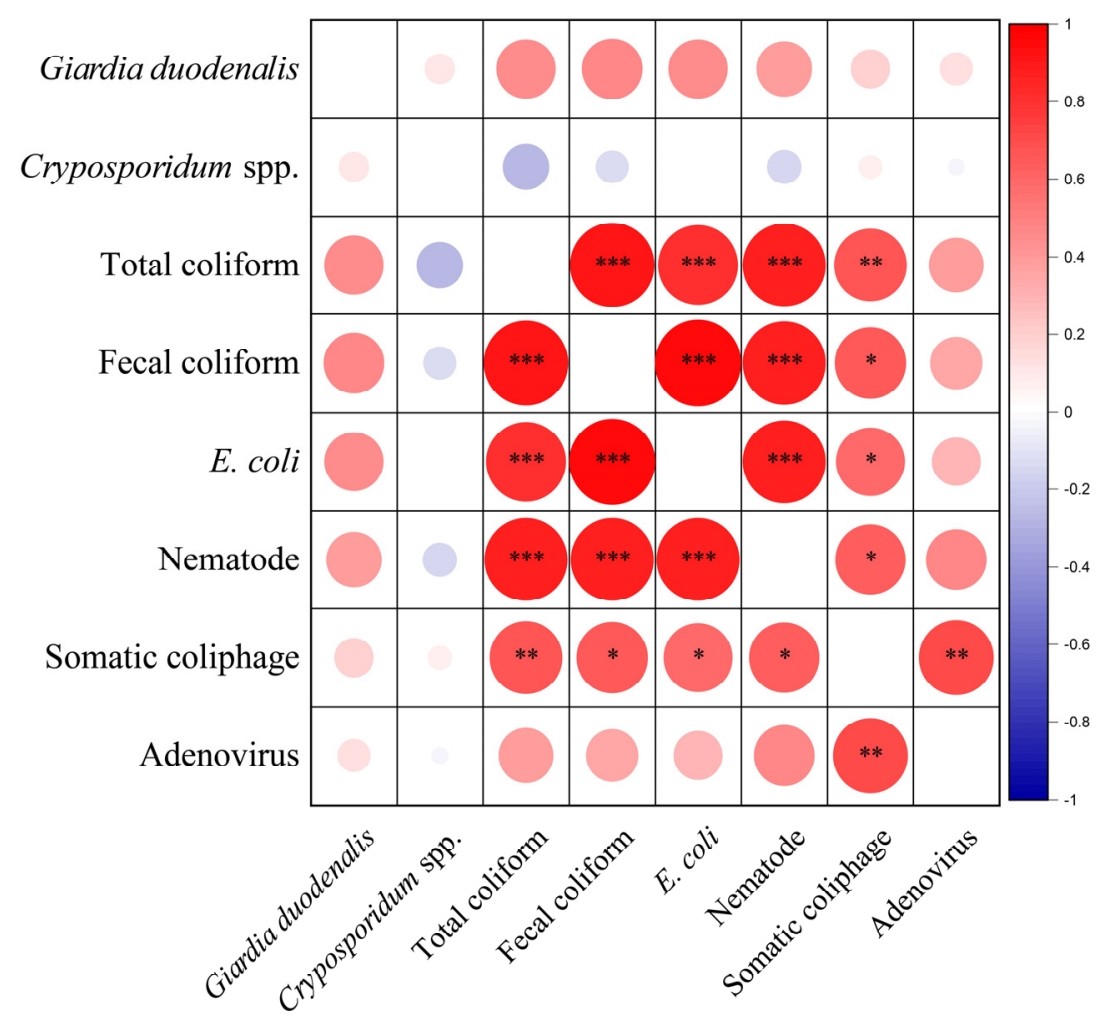

Figure 6. Correlogram showing the relationships among pathogens and indicators. ${ }^{*} p \leq 0.05$, ${ }^{* *} p \leq 0.01,{ }^{* * *} p \leq 0.001$.

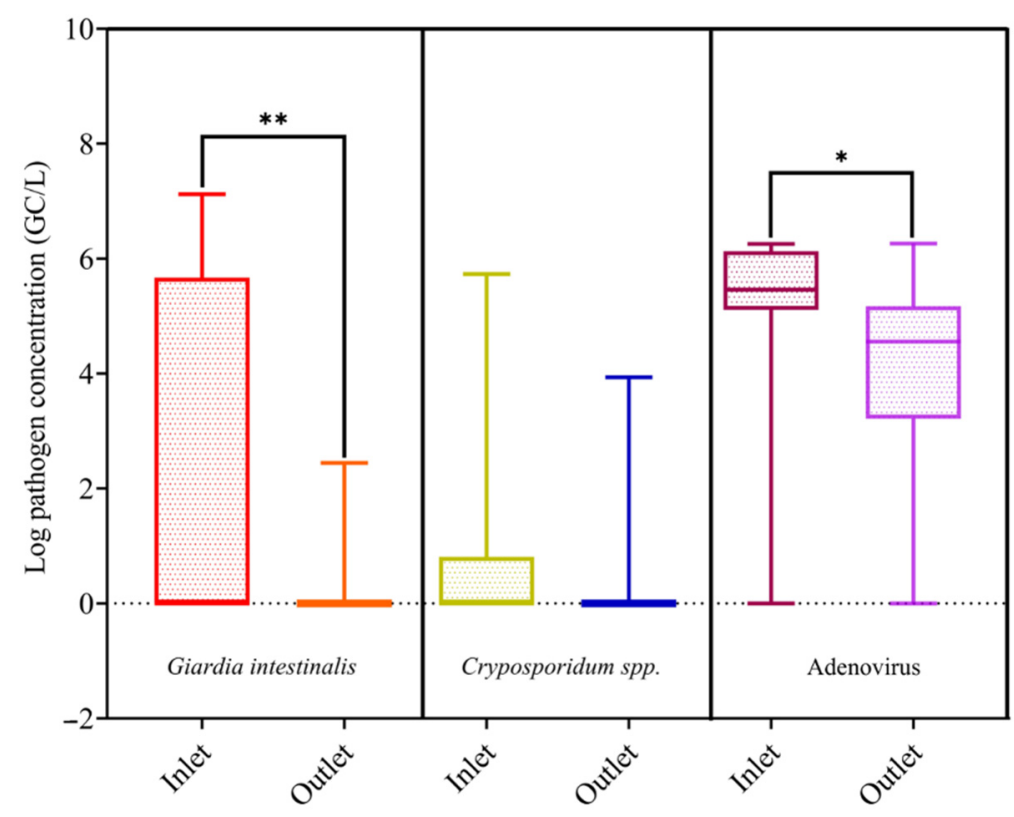

Figure 7. Box and whiskers plot showing the concentrations of protozoan and viral pathogens in inlet and outlet samples. ${ }^{*} p \leq 0.05,{ }^{* *} p \leq 0.01$. 


\section{Conclusions}

The integrated system, which includes HRAP as a core stage, can provide effective oxidation of wastewater organic compounds, increase nutrient removal, and remove pathogens and indicators. Multivariate statistical models showed a strongly significant difference between inlet and outlet samples, indicating the influence of the wastewater treatment in improving the quality of the effluents. The system presented here achieved $92.09 \%, 89.39 \%, 89.26 \%$, and $82.24 \%$ reduction of $\mathrm{TSS}, \mathrm{NH}_{4}-\mathrm{N}, \mathrm{BOD}$, and COD, respectively. A reduction of $\sim 5.6 \log _{10}$ was found for bacterial indicators, and viral removal ranged between 0.88 and $1.65 \log _{10}$. The mean removal of Cryptosporidium spp. and Giardia intestinalis genes were 0.52 and $2.42 \log _{10}$, respectively. Interestingly, the integrated system achieved $100 \%$ removal of parasitic helminth ova in the treated effluent, suggesting that the system can safely reduce human exposure to pathogens. Importantly, the treated effluents were shown to meet the Egyptian standards for agriculture wastewater reuse. Hence, HRAP technology can be an appropriate alternative for combining wastewater treatment and bioenergy recovery. Further research is needed to investigate the removal efficiency for a broad range of pathogens and explore mechanisms responsible for pathogen removal in HRAPs. This will provide the scientific basis necessary for improving the design and operation of HRAPs for pathogen removal.

Supplementary Materials: The following are available online at https://www.mdpi.com/article/ 10.3390/su132313232/s1. Table S1. Community structure of algae in HRAP system. Table S2. Average characteristics of the Raw and the effluent from each treatment unit. Figure S1. Showing algal species under light microscope. (1) Pediastrumgracilimum, (2) Scenedismus quadriqauda, (3) Dictyospharium sp. (4) Gloenkenia sp., (5) Eugleana sp. Figure S2. Heatmap showing the nematode ova counts in different stages of the integrated system.

Author Contributions: S.A.-E.: Conceptualization, formal analysis, writing-original draft. S.M.A.: Methodology, validation, writing - review and editing. M.G.: Conceptualization, methodology, visualization, writing - review and editing. A.H.: Software, review and editing. M.A.E.-L.: Investigation, methodology, writing-review. N.R.: Methodology, data curation, writing. I.A.H.: Methodology, writing - review and editing. M.A.M.: Investigation, methodology, data curation. H.S.D.: Conceptualization, writing, resources, funding acquisition. All authors have read and agreed to the published version of the manuscript.

Funding: The work was financially supported by the Academy of Scientific Research and Technology (ASRT), Egypt, grant number 4504.

Data Availability Statement: The datasets used and analyzed during the current study are available from the corresponding author upon reasonable request.

Acknowledgments: The cooperation with Anyi Hu is under an agreement between the National Research Centre (Egypt) and the Institute of Urban Environment, Chinese Academy of Sciences (China).

Conflicts of Interest: The authors declare no conflict of interest.

\section{References}

1. United Nations Statistical Commission (UNSC). United Nations Technical Report by the Bureau of the United Nations Statistical Commission (UNSC) on the Process of the Development of an Indicator Framework for the Goals and Targets of the Post-2015 Development Agenda (Working Draft). 19 March 2015. Available online: https://sustainabledevelopment.un.org/index.php? page $=$ view \&type $=111 \& n r=6754 \&$ menu $=35$ (accessed on 10 November 2021$)$.

2. United Nations. The Millennium Development Goals Report; United Nations: New York, NY, USA, 2015; p. 72, ISBN 978-92-1-101320-7.

3. WHO. Sanitation Sheet Fact; World Health Organization: Geneva, Switzerland, 2019.

4. Baum, R.; Luh, J.; Bartram, J. Sanitation: A global estimate of sewerage connections without treatment and the resulting impact on MDG progress. Environ. Sci. Technol. 2013, 47, 1994-2000. [CrossRef]

5. García-Aljaro, C.; Blanch, A.R.; Campos, C.; Jofre, J.; Lucena, F. Pathogens, faecal indicators and human-specific microbial source-tracking markers in sewage. J. Appl. Microbiol. 2019, 126, 701-717. [CrossRef]

6. Li, Y.; Zhu, G.; Ng, W.J.; Tan, S.K. A review on removing pharmaceutical contaminants from wastewater by constructed wetlands: Design, performance and mechanism. Sci. Total Environ. 2014, 468-469, 908-932. [CrossRef] [PubMed] 
7. Chen, Y.; Wen, Y.; Zhou, Q.; Vymazal, J. Effects of plant biomass on denitrifying genes in subsurface-flow constructed wetlands. Bioresour. Technol. 2014, 157, 341-345. [CrossRef] [PubMed]

8. Wu, H.; Zhang, J.; Li, C.; Fan, J.; Zou, Y. Mass Balance Study on Phosphorus Removal in Constructed Wetland Microcosms Treating Polluted River Water. CLEAN Soil Air Water 2013, 41, 844-850. [CrossRef]

9. Noyola, A.; Padilla-Rivera, A.; Morgan-Sagastume, J.M.; Güereca, L.P.; Hernández-Padilla, F. Typology of Municipal Wastewater Treatment Technologies in Latin America. CLEAN Soil Air Water 2012, 40, 926-932. [CrossRef]

10. Verbyla, M.E. Pathogen Removal in Natural Wastewater Treatment and Resource Recovery Systems: Solutions for Small Cities in an Urbanizing World; University of South Florida: Tampa, FL, USA, 2015; ISBN 1339288516.

11. Bhuyar, P.; Trejo, M.; Dussadee, N.; Unpaprom, Y.; Ramaraj, R.; Whangchai, K. Microalgae cultivation in wastewater effluent from tilapia culture pond for enhanced bioethanol production. Water Sci. Technol. 2021. [CrossRef]

12. Bhuyar, P.; Hong, D.D.; Mandia, E.; Rahim, M.H.A.; Maniam, G.P.; Govindan, N. Desalination of polymer and chemical industrial wastewater by using green photosynthetic microalgae, Chlorella sp. Maejo Int. J. Energy Environ. Commun. 2019, 1, 9-19. [CrossRef]

13. Buchanan, N.A.; Young, P.; Cromar, N.J.; Fallowfield, H.J. Performance of a high rate algal pond treating septic tank effluent from a community wastewater management scheme in rural South Australia. Algal Res. 2018, 35, 325-332. [CrossRef]

14. Fallowfield, H.J.; Young, P.; Taylor, M.J.; Buchanan, N.; Cromar, N.; Keegan, A.; Monis, P. Independent validation and regulatory agency approval for high rate algal ponds to treat wastewater from rural communities. Environ. Sci. Water Res. Technol. 2018, 4, 195-205. [CrossRef]

15. Vassalle, L.; Díez-Montero, R.; Machado, A.T.R.; Moreira, C.; Ferrer, I.; Mota, C.R.; Passos, F. Upflow anaerobic sludge blanket in microalgae-based sewage treatment: Co-digestion for improving biogas production. Bioresour. Technol. 2020, $300,122677$. [CrossRef] [PubMed]

16. Young, P.; Buchanan, N.; Fallowfield, H.J. Inactivation of indicator organisms in wastewater treated by a high rate algal pond system. J. Appl. Microbiol. 2016, 121, 577-586. [CrossRef] [PubMed]

17. Arslan-Alaton, I.; Olmez-Hanci, T. Green Technologies for Wastewater Treatment: Energy Recovery and Emerging Compounds Removal; Springer: Berlin/Heidelberg, Germany, 2012; ISBN 978-94-007-1430-4.

18. Muñoz, R.; Guieysse, B. Algal-bacterial processes for the treatment of hazardous contaminants: A review. Water Res. 2006, 40, 2799-2815. [CrossRef]

19. Craggs, R.J. Advanced integrated wastewater ponds. In Pond Treatment Technology; IWA Scientific and Technical Report Series; IWA: London, UK, 2005; pp. 282-310.

20. Mara, D. Domestic Wastewater Treatment in Developing Countries, Earthscan; James \& James: London, UK, 2004; ISBN 1-84407-019-0.

21. Araki, S.; Martın-Gomez, S.; Bécares, E.; De Luis-Calabuig, E.; Rojo-Vazquez, F. Effect of high-rate algal ponds on viability of Cryptosporidium parvum oocysts. Appl. Environ. Microbiol. 2001, 67, 3322-3324. [CrossRef] [PubMed]

22. Bolton, N.F.; Cromar, N.J.; Hallsworth, P.; Fallowfield, H.J. A review of the factors affecting sunlight inactivation of microorganisms in waste stabilisation ponds: Preliminary results for enterococci. Water Sci. Technol. 2010, 61, 885-890. [CrossRef] [PubMed]

23. El Hamouri, B.; Rami, A.; Vasel, J.-L. The reasons behind the performance superiority of a high rate algal pond over three facultative ponds in series. Water Sci. Technol. 2003, 48, 269-276. [CrossRef] [PubMed]

24. Buchanan, N.; Cromar, N.; Bolton, N.; Fallowfield, H. Comparison of a high rate algal pond with a standard secondary facultative waste stabilisation pond in rural South Australia. In Proceedings of the 10th Specialised Conference on Small Water and Wastewater Treatment Systems, Venice, Italy, 18-22 April 2011; pp. 292-299.

25. Espinosa, M.F.; Verbyla, M.E.; Vassalle, L.; Rosa-Machado, A.T.; Zhao, F.; Gaunin, A.; Mota, C.R. Reduction and partitioning of viral and bacterial indicators in a UASB reactor followed by high rate algal ponds treating domestic sewage. Sci. Total Environ. 2021, 760, 144309. [CrossRef]

26. Picot, B.; Bahlaoui, A.; Moersidik, S.; Baleux, B.; Bontoux, J. Comparison of the purifying efficiency of high rate algal pond with stabilization pond. Water Sci. Technol. 1992, 25, 197-206. [CrossRef]

27. Chambonniere, P.; Bronlund, J.; Guieysse, B. Pathogen removal in high-rate algae pond: State of the art and opportunities. Appl Phycol. 2021, 33, 1501-1511. [CrossRef]

28. Hindiyeh, M.Y.; Al-Salem, S.; Malkawi, M.; Kofahi, A.; Al-Yaman, R.; Shugen, A. Integrated Guide to Sanitry Parasitology; World Health Organization: Geneva, Switzerland, 2004; pp. 1-124.

29. Jamieson, R.; Gordon, R.; Joy, D.; Lee, H. Assessing microbial pollution of rural surface waters: A review of current watershed scale modeling approaches. Agric. Water Manag. 2004, 70, 1-17. [CrossRef]

30. Boutilier, L.; Jamieson, R.; Gordon, R.; Lake, C.; Hart, W. Adsorption, sedimentation, and inactivation of E. coli within wastewater treatment wetlands. Water Res. 2009, 43, 4370-4380. [CrossRef] [PubMed]

31. Liu, L.; Hall, G.; Champagne, P. The role of algae in the removal and inactivation of pathogenic indicator organisms in wastewater stabilization pond systems. Algal Res. 2020, 46, 101777. [CrossRef]

32. Momba, M.; Ebdon, J.; Kamika, I.; Verbyla, M. Using indicators to assess microbial treatment and disinfection efficacy. In Global Water Pathogen Project; Michigan State University Press: East Lansing, MI, USA, 2019.

33. Nasr, F.A.; Gad, M.A.; Al-Herrawy, A.Z.; Abdelfadil, A.S. Decentralized biological compact unit for the removal of parasitic helminth ova during sewage treatment. EnvironmentAsia 2019, 12, 178-186. [CrossRef] 
34. Rizk, N.M.; Hamza, I.A. Molecular Quantification of Human Bocavirus in Environmental Water Samples in Giza, Egypt. Egypt. J. Aquat. Biol. Fish. 2021, 25, 735-749. [CrossRef]

35. Doma, H.S.; El-Liethy, M.A.; Abdo, S.M.; Ali, G.H. Potential of using high rate algal pond for algal biofuel production and wastewater treatment. Asian J. Chem. 2016, 28, 399. [CrossRef]

36. Baird, R.B.; Eaton, A.D. APHA Standard Methods for Examination of Water and Wastewater, 23rd ed.; American Public Health Association: Washington, DC, USA, 2017; ISBN 0875530478.

37. Bhuyar, P.; Sundararaju, S.; Rahim, M.H.A.; Ramaraj, R.; Maniam, G.P.; Govindan, N. Microalgae cultivation using palm oil mill effluent as growth medium for lipid production with the effect of CO2 supply and light intensity. Biomass Convers. Biorefinery 2021, 11, 1555-1563. [CrossRef]

38. ISO 10705-2: Water Quality. Detection and Enumeration of Bacteriophages-Part 2: Enumeration of Somatic Coliphages; International Organization for Standardization: Geneva, Switzerland, 2000; pp. 1-16.

39. Williams, F.P.; Stetler, R.E.; Safferman, R.S. USEPA Manual of Methods for Virology; U.S. Environmental Protection Agency: Washington, DC, USA, 2001; Volume 600, pp. 4-84.

40. Moodley, P.; Archer, C.; Hawksworth, D. Standard Methods for the Recovery and Enumeration of Helminth Ova in Wastewater, Sludge, Compost and Urine-Diversion Waste in South Africa; Water Research Commission (WRC): Pretoria, South Africa, 2008; ISBN 9781770056480.

41. Heim, A.; Ebnet, C.; Harste, G.; Pring-Åkerblom, P. Rapid and quantitative detection of human adenovirus DNA by real-time PCR. J. Med. Virol. 2003, 70, 228-239. [CrossRef]

42. Haque, R.; Roy, S.; Siddique, A.; Mondal, U.; Rahman, S.M.M.; Mondal, D.; Houpt, E.; Petri, W.A. Multiplex real-time PCR assay for detection of Entamoeba histolytica, Giardia intestinalis, and Cryptosporidium spp. Am. J. Trop. Med. Hyg. 2007, 76, 713-717. [CrossRef] [PubMed]

43. Guy, R.A.; Payment, P.; Krull, U.J.; Horgen, P.A. Real-time PCR for quantification of Giardia and Cryptosporidium in environmental water samples and sewage. Appl. Environ. Microbiol. 2003, 69, 5178-5185. [CrossRef]

44. Gad, M.; Hou, L.; Li, J.; Wu, Y.; Rashid, A.; Chen, N.; Hu, A. Distinct mechanisms underlying the assembly of microeukaryotic generalists and specialists in an anthropogenically impacted river. Sci. Total Environ. 2020, 748, 1-12. [CrossRef]

45. Reynolds, C.S. Environmental requirements and habitat preferences of phytoplankton: Chance and certainty in species selection. Bot. Mar. 2012, 55, 1-17. [CrossRef]

46. Assemany, P.; Calijuri, M.L.; Couto, E.D.A.D.; de Souza, M.H.B.; Silva, N.C.; Santiago, A.; Castro, J. Algae/bacteria consortium in high rate ponds: Influence of solar radiation on the phytoplankton community. Ecol. Eng. 2015, 77, 154-162. [CrossRef]

47. Craggs, R.J.; Davies-Colley, R.J.; Tanner, C.C.; Sukias, J.P. Advanced pond system: Performance with high rate ponds of different depths and areas. Water Sci. Technol. 2003, 48, 259-267. [CrossRef]

48. El Hafiane, F.; El Hamouri, B. Anaerobic reactor/high rate pond combined technology for sewage treatment in the Mediterranean area. Water Sci. Technol. 2005, 51, 125-132. [CrossRef] [PubMed]

49. Buchanan, A.N. Comparing the Performance of a High Rate Algal Pond with a Waste Stabilisation Pond in Rural South Australia. Ph.D. Thesis, Flinders University, School of the Environment, Adelaide, SA, Australia, 2014.

50. El Hamouri, B.; Jellal, J.; Outabiht, H.; Nebri, B.; Khallayoune, K.; Benkerroum, A.; Hajli, A.; Firadi, R. The performance of a high-rate algal pond in the Moroccan climate. Water Sci. Technol. 1995, 31, 67-74. [CrossRef]

51. Park, J.B.K.; Craggs, R.J. Wastewater treatment and algal production in high rate algal ponds with carbon dioxide addition. Water Sci. Technol. 2010, 633-639. [CrossRef]

52. Sutherland, D.L.; Howard-Williams, C.; Turnbull, M.H.; Broady, P.A.; Craggs, R.J. Seasonal variation in light utilisation, biomass production and nutrient removal by wastewater microalgae in a full-scale high-rate algal pond. J. Appl. Phycol. 2014, 26, 1317-1329. [CrossRef]

53. Santiago, A.F.; Calijuri, M.D.C.; Assemany, P.; Reis, A. Algal biomass production and wastewater treatment in high rate algal ponds receiving disinfected effluent. Environ. Technol. 2013, 34, 1877-1885. [CrossRef]

54. Chen, P.; Zhou, Q.; Paing, J.; Le, H.; Picot, B. Nutrient removal by the integrated use of high rate algal ponds and macrophyte systems in China. Water Sci. Technol. 2003, 48, 251-257. [CrossRef]

55. El Hamouri, B. Rethinking natural, extensive systems for tertiary treatment purposes: The high-rate algae pond as an example. Desalination Water Treat. 2009, 4, 128-134. [CrossRef]

56. Young, P.; Taylor, M.; Fallowfield, H.J. Mini-review: High rate algal ponds, flexible systems for sustainable wastewater treatment. World J. Microbiol. Biotechnol. 2017, 33, 117. [CrossRef]

57. Craggs, R.J.; Heubeck, S.; Lundquist, T.J.; Benemann, J.R. Algal biofuels from wastewater treatment high rate algal ponds. Water Sci. Technol. 2011, 63, 660-665. [CrossRef]

58. Rawat, I.; Kumar, R.R.; Mutanda, T.; Bux, F. Dual role of microalgae: Phycoremediation of domestic wastewater and biomass production for sustainable biofuels production. Appl. Energy 2011, 88, 3411-3424. [CrossRef]

59. Chambonniere, P.; Bronlund, J.; Guieysse, B. Escherichia coli removal during domestic wastewater treatment in outdoor high rate algae ponds: Long-term performance and mechanistic implications. Water Sci. Technol. 2020, 82, 1166-1175. [CrossRef]

60. Harwood, V.; Shanks, O.; Koraijkic, A.; Verbyla, M.; Ahmed, W.; Iriate, M. General and host-associated bacterial indicators of faecal pollution. In Water and Sanitation for the 21st Century: Health and Microbiological Aspects of Excreta and Wastewater Management; Rose, J.B., Jiménez-Cisneros, B., Eds.; Michigan State University: East Lansing, MI, USA, 2017. 
61. WHO. Guidelines for the Safe Use of Wastewater, Excreta and Greywater: Vol. 1: Policy and Regulatory Aspects; World Health Organization: Geneva, Switzerland, 2006.

62. Fong, T.-T.; Griffin, D.W.; Lipp, E.K. Molecular assays for targeting human and bovine enteric viruses in coastal waters and their application for library-independent source tracking. Appl. Environ. Microbiol. 2005, 71, 2070-2078. [CrossRef] [PubMed]

63. Hot, D.; Legeay, O.; Jacques, J.; Gantzer, C.; Caudrelier, Y.; Guyard, K.; Lange, M.; Andreoletti, L. Detection of somatic phages, infectious enteroviruses and enterovirus genomes as indicators of human enteric viral pollution in surface water. Water Res. 2003, 37, 4703-4710. [CrossRef]

64. Ashbolt, N.J.; Grabow, W.O.K.; Snozzi, M. Indicators of microbial water quality. In Water Quality: Guidelines, Standards and Health; IWA Publishing: London, UK, 2001; pp. 289-316.

65. Araki, S.; González, J.M.; De Luis, E.; Bécares, E. Viability of nematode eggs in high rate algal ponds: The effect of physico-chemical conditions. Water Sci. Technol. 2000, 42, 371-374. [CrossRef]

66. Von Sperling, M.; Mascarenhas, L. Performance of very shallow ponds treating effluents from UASB reactors. Water Sci. Technol. 2005, 51, 83-90. [CrossRef] [PubMed]

67. Tyagi, V.K.; Kazmi, A.A.; Chopra, A.K. Removal of fecal indicators and pathogens in a waste stabilization pond system treating municipal wastewater in India. Water Environ. Res. 2008, 80, 2111-2117. [CrossRef]

68. Nelson, K.L.; Cisneros, B.J.; Tchobanoglous, G.; Darby, J.L. Sludge accumulation, characteristics, and pathogen inactivation in four primary waste stabilization ponds in central Mexico. Water Res. 2004, 38, 111-127. [CrossRef] [PubMed]

69. Sheludchenko, M.; Padovan, A.; Katouli, M.; Stratton, H. Removal of fecal indicators, pathogenic bacteria, Adenovirus, Cryptosporidium and Giardia (oo) cysts in waste stabilization ponds in Northern and Eastern Australia. Int. J. Environ. Res. Public Health 2016, 13, 96. [CrossRef]

70. Armanious, A.; Aeppli, M.; Jacak, R.; Refardt, D.; Sigstam, T.; Kohn, T.; Sander, M. Viruses at Solid-Water Interfaces: A Systematic Assessment of Interactions Driving Adsorption. Environ. Sci. Technol. 2016, 50, 732-743. [CrossRef] [PubMed]

71. Yin, Z.; Voice, T.C.; Tarabara, V.V.; Xagoraraki, I. Sorption of human adenovirus to wastewater solids. J. Environ. Eng. 2018, 144, 6018008. [CrossRef]

72. Davies-Colley, R.J.; Craggs, R.J.; Park, J.; Sukias, J.P.S.; Nagels, J.W.; Stott, R. Virus removal in a pilot-scale "advanced" pond system as indicated by somatic and F-RNA bacteriophages. Water Sci. Technol. 2005, 51, 107-110. [CrossRef]

73. Sinton, L.W.; Hall, C.H.; Lynch, P.A.; Davies-Colley, R.J. Sunlight inactivation of fecal indicator bacteria and bacteriophages from waste stabilization pond effluent in fresh and saline waters. Appl. Environ. Microbiol. 2002, 68, 1122-1131. [CrossRef] [PubMed]

74. Mattle, M.J.; Vione, D.; Kohn, T. Conceptual model and experimental framework to determine the contributions of direct and indirect photoreactions to the solar disinfection of MS2, phiX174, and adenovirus. Environ. Sci. Technol. 2015, 49, 334-342. [CrossRef]

75. Kohn, T.; Mattle, M.J.; Minella, M.; Vione, D. A modeling approach to estimate the solar disinfection of viral indicator organisms in waste stabilization ponds and surface waters. Water Res. 2016, 88, 912-922. [CrossRef] [PubMed] 